Received Date : 17-Jun-2014

Revised Date : 29-Oct-2014

Accepted Date : 30-Oct-2014

Article type : Original Article: Experimental Allergy and Immunology

Editor $\quad$ : Hans-Uwe Simon

\title{
Eotaxin-3 (CCL26) exerts innate host defense activities that are modulated by mast cell proteases
}

Anele Gela, ${ }^{1}$ Gopinath Kasetty, ${ }^{1}$ Sandra Jovic, ${ }^{1}$ Maria Ekoff, ${ }^{5}$ Gunnar Nilsson, ${ }^{5}$ Matthias Mörgelin, ${ }^{2}$ Sven Kjellström, ${ }^{4}$ James E. Pease, ${ }^{6}$ Artur Schmidtchen, ${ }^{3}$ Arne Egesten ${ }^{1}$

Respiratory Medicine \& Allergology, ${ }^{1}$ Infection Medicine, ${ }^{2}$ and Dermatology \& Venerology, ${ }^{3}$ Department of Clinical Sciences Lund; Molecular and Protein Science, Institute for Chemistry and Chemical Engineering, ${ }^{4}$ Lund University; Clinical Immunology and Allergy Unit, ${ }^{4}$ Department of Medicine, Karolinska Institutet, Stockholm, Sweden. Leukocyte Biology Section, ${ }^{6}$ NHLI, Faculty of Medicine, Imperial College of Science, Technology, and Medicine, London SW7 2AZ, United Kingdom.

Short title: Host defense activities of eotaxins

This article has been accepted for publication and undergone full peer review but has not been through the copyediting, typesetting, pagination and proofreading process, which may lead to differences between this version and the Version of Record. Please cite this article as doi: $10.1111 /$ all.12542

This article is protected by copyright. All rights reserved. 
Address correspondence to: Anele Gela, BMC B14, Tornavägen 10, SE-221 84 Lund, Sweden. Phone: +46 46222 7118. E-mail: Anele.Gela@med.lu.se

\begin{abstract}
Background

During bacterial infections of the airways, a Th1-profiled inflammation promotes the production of several host defense proteins and peptides with antibacterial activities including $\beta$-defensins, ELRnegative CXC-chemokines, and the cathelicidin LL-37. These are down-regulated by Th2 cytokines of the allergic response. Instead, the eosinophil-recruiting chemokines eotaxin-1/CCL11, eotaxin2/CCL24, and eotaxin-3/CCL26 are expressed. This study set out to investigate if these chemokines could serve as innate host defense molecules during allergic inflammation.
\end{abstract}

\title{
Methods
}

Antibacterial activities of the eotaxins were investigated using viable count assays, electron microscopy, and methods assessing bacterial permeabilization. Fragments generated by mast cell proteases were characterized and their potential antibacterial, receptor-activating, and lipopolysaccharide-neutralizing activities were investigated.

\section{Results}

CCL11, CCL24, and CCL26 all showed potent bactericidal activity, mediated through membranedisruption, against the airway pathogens Streptococcus pneumoniae, Staphylococcus aureus, Nontypeable Haemophilus influenzae, and Pseudomonas aeruginosa. CCL26 retained bactericidal activity in the presence of salt at physiologic concentrations and the region holding the highest bactericidal activity was the cationic and amphiphatic COOH-terminus. Proteolysis of CCL26 by chymase and This article is protected by copyright. All rights reserved. 
tryptase respectively, released distinct fragments of the $\mathrm{COOH}-$ and $\mathrm{NH}_{2}$-terminal regions. The $\mathrm{COOH}$-terminal fragment retained antibacterial activity while the $\mathrm{NH}_{2}$-terminal had potent LPSneutralizing properties in the order of CCL26 full length protein. An identical fragment to $\mathrm{NH}_{2}-$ terminal fragment generated by tryptase was obtained after incubation with supernatants from activated mast cells. None of the fragments activated the CCR3-receptor.

\section{Conclusions}

Taken together, the findings show that eotaxins can contribute to host defense against common airway pathogens and that their activities are modulated by mast cell proteases.

Key words: Allergy; Bacterial infection; Eotaxins; Host defense

\section{INTRODUCTION}

During normal conditions, several arms of host defense protect our airways from infection. Effector molecules include constitutively produced host defense proteins and peptides (HDPs) with antibacterial activity. These are present in the thin periciliary liquid layer of the airways and include lactoferrin, lysozyme, and SLPI (1). Upon bacterial infection, a Th1 inflammatory response induces the expression of additional HDPs, for example the $\beta$-defensins hBD-2 and hBD-3 and the cathelicidin-derived peptide LL-37 (2-5). In addition, several chemokines, constitutively expressed or induced during Th1-profiled inflammation, have defensin-like antibacterial properties, e.g. CCL20, CCL28, MIG/CXCL9, CXCL17 and GCP-2/CXCL6 (6-10).

During allergic asthma, high presence of eosinophils is a hallmark of the disease. This results from a Th2-profiled inflammatory response including release of eotaxin-1/CCL11, eotaxin-2/CCL24, and

This article is protected by copyright. All rights reserved. 
eotaxin-3/CCL26 that bind and activate the seven transmembrane G-coupled CCR3 receptor present on eosinophils, thereby regulating eosinophil trafficking into the airways alongside with other chemotactic factors (11). Similar to other chemokines and defensins, eotaxin 1-3 comprise a typical chemokine fold, which includes a 3 -stranded $\beta$-sheet and an overlying $\alpha$-helix and two adjacent cysteine residues close to the N-terminus (12). In addition to eosinophils, mast cells are key players during allergic inflammation, releasing several potent molecules affecting the inflamed environment including histamine and proteases. Thus, the mast cell proteases chymase and tryptase may modulate the actions of chemokines, e.g. the eotaxins (13).

There is an increased risk of pneumococcal infection in asthma and pneumococcal carriage is more common in asthmatic than in non-asthmatic individuals (14). In one study, more than half of patients with stable severe asthma were colonized with bacterial pathogens in their lower airways, Haemophilus influenzae, Pseudomonas aeruginosa, and Staphylococcus aureus being the most common bacteria (15).

In this study, we investigated whether the eotaxins could play a role as HDPs, exerting antibacterial activities, during the Th2-skewed inflammation seen in allergic asthma. We found potent bactericidal activity of the eotaxins, in particular of CCL26. In addition, we show that chymase and tryptase modulate the receptor-activating properties of CCL26. Taken together, the eotaxins may contribute to host defense of the airways during allergic inflammation but their activities are modulated by the mast cell proteases.

\section{MATERIALS AND METHODS}

Details of the methods used in this study are provided in the Supporting Information.

This article is protected by copyright. All rights reserved. 


\section{Viable Count Assay}

The procedure is described in detail in Supporting Information S1.

\section{Scanning electron microscopy}

The procedure is described in detail in Supporting Information S1.

\section{Detection of membrane permeabilization}

The procedure is described in detail in Supporting Information S1.

\section{Radial Diffusion Assay}

The procedure is described in detail in Supporting Information S1.

\section{Proteolytic cleavage of eotaxins and SDS-PAGE}

The procedure is described in detail in Supporting Information S1.

\section{Mass spectrometry}

Coomassie-stained gel bands were extracted and subjected to reversed phase HPLC separation followed by LC-MS/MS. Automated N-terminal sequencing was performed using a Procise 494 instrument from Applied Biosystems. This is described in detail in Supporting Information S1.

This article is protected by copyright. All rights reserved. 


\section{Endotoxin-neutralizing effect}

The procedure is described in detail in Supporting Information S1.

\section{Calcium mobilization assay}

A murine cell line stably expressing human CCR3 was loaded with calcium-sensitive fluorophore and used to investigate mobilization of intracellular calcium. This is described in detail in Supporting Information S1.

\section{Chemotaxis assay}

The procedure is described in detail in Supporting Information S1.

\section{Statistical analysis}

Statistical significances were evaluated using Graph Pad Prism (Graph Pad software, La Jolla, CA) and tested using two-way analysis of variance (ANOVA).

\section{RESULTS}

\section{Eotaxin 1-3 (CCL11, CCL24, and CCL26) exert bactericidal activity}

Eotaxin-1/CCL11, Eotaxin-2/CCL24 and Eotaxin-3/CCL26 were investigated for antibacterial activity against Gram-positive (i.e S. aureus and S. pneumoniae) and Gram-negative pathogens (i.e. $P$. aeruginosa and $\mathrm{NtHi}$ ) using a viable count assay (Figure 1A). The results demonstrate a dosedependent killing of bacteria, which was compared to the classical cathelicidin-derived antimicrobial peptide, LL-37. In the case of $S$. aureus and P. aeruginosa, CCL24 and, in particular CCL26, showed

This article is protected by copyright. All rights reserved. 
high bactericidal activity at concentrations of $0.1 \mu \mathrm{M}$, being approximately tenfold more potent than LL-37 and CCL11 (Figure 1A). The bactericidal activity of the three eotaxins against S. pneumoniae was similar while CCL24 and CCL26 was more active against NtHi compared to CCL11 (Figure 1A). The antimicrobial activity of both CCL11 and CCL24 against S. pneumoniae decreased to some extent in the presence of salt at a concentration similar to that likely to be present in the airway surface liquid (i.e. $140 \mathrm{mM}$ ) (16). However, CCL26 retained its bactericidal activity against $S$. pneumoniae in the presence of salt (Figure 1B).

\section{Morphological alterations of bacteria after incubation with eotaxins}

Antimicrobial peptides are known to exert their activity through disruption of bacterial membranes (17). To investigate if the eotaxins have membrane-disruptive properties, the different bacterial strains were incubated in buffer alone, with the eotaxins (CCL11, CCL24, or CCL26), or with LL-37 (the latter serving as a positive control) and analyzed by scanning electron microscopy. Incubation with CCL11, CCL24, CCL26, and LL37 all resulted in bacterial blebbing and disruption, with concomitant leakage of cytoplasmic material to the extracellular environment (Figure 2). After incubation in buffer alone, the bacteria remained intact.

\section{Membrane-disrupting properties of CCL26}

To further investigate a possible membrane-disrupting activity of CCL26, FITC, a probe being impermeant in viable cells but taken up intracellularly by disrupted cells, was used (18). An increased uptake of FITC was observed when S. pneumoniae was incubated with CCL26 or LL37, the latter used as a positive control (both at $1 \mu \mathrm{M}$ ) (Figure 3A). To confirm loss of bacterial membrane integrity after incubation with CCL26, the entry of propidium iodide (PI) into bacteria was investigated. When PI is internalized, it binds DNA, emitting red fluorescence upon excitation. For this purpose, flow cytometry was used to detect internalization of PI following one hour of incubation with CCL26 (1

This article is protected by copyright. All rights reserved. 
$\mu \mathrm{M})$. After incubation with CCL26, significantly higher fluorescence was seen compared with bacteria incubated in buffer alone, further demonstrating loss of bacterial membrane integrity after incubation with this eotaxin (Figure 3B).

\section{Mapping of the bactericidal activity in CCL26}

As shown in Figure 1, CCL26 had the most potent bactericidal activity at physiological salt concentration. To delineate the regions of CCL26 that harbors the antimicrobial activity, a radial diffusion assay was used (Figure 4). Overlapping 20-mer synthetic peptides derived from the CCL26 full length protein were screened for antimicrobial activity against $P$. aeruginosa and $S$. aureus. The results show potent antimicrobial activity by the fragments derived from the cationic $\mathrm{COOH}$-terminal domain of the peptide (Figure 3).

\section{Processing of CCL26 by mast cell proteases}

Mast cells are important effector cells during allergic inflammation and release the serine proteases chymase and tryptase, having the capacity to modulate host defense effector functions (13). To investigate whether the eotaxins are proteolytically cleaved or degraded by these proteases, the chemokines were incubated with chymase and typtase for 18 hours, respectively. Thereafter, the generated peptides were separated on Tris-Tricine gels and stained with Coomassie staining. Digestion by chymase and tryptase each yielded one distinct fragment (Figure 5A). The chymasederived fragment contained 25 amino acids (TTK25) and spanned the amphiphatic COOH-terminal. The tryptase-derived fragment contained 35 amino acids (GSD35) and was derived from the $\mathrm{NH}_{2}-$ terminal including the anti-parallel $\beta$-strands (Figure 4A). When comparing the biophysical properties, TTK25 has a higher net charge (+9) and pI (10.8) compared with GSD35 (net charge of +2 and pI 8.6) (Table 1).

This article is protected by copyright. All rights reserved. 
To investigate degradation of CCL26 in a more physiological context, supernatants from degranulated in vitro derived mast cells were incubated with this chemokine (Figure 5A). This resulted in a distinct fragment identical with an $\mathrm{NH}_{2}$-terminal sequence. A combination of $\mathrm{N}$-terminal sequencing and MS/MS showed the fragment to be identical to the tryptase-generated GSD35 fragment but appearing slightly smaller on SDS-PAGE. A serine-protease inhibitor (Pefabloc SC) inhibited generation of the fragment.

To compare the antibacterial activity of full-length CCL26 and the fragments (TTK25 and GSD35), dose-response experiments were performed using the viable counts assay (Figure 5B). TTK25 had an antibacterial activity in the order of full-length CCL26 except at $0.5 \mu \mathrm{M}$ against $S$. pneumoniae, where it showed lower activity. GSD35 showed weak antibacterial activity against both $S$. pneumoniae and $\mathrm{NtHi}$. This is in line with the mapping experiments shown in Figure 4.

A few HDPs have LPS-neutralizing capacity (19). To investigate if this is the case for CCL26 and the protease-derived fragments, LPS from $P$. aeruginosa and a monocytic cell-line with an NF-kappaB sensitive reporter gene was used. Interestingly, GSD35 showed high LPS-neutralizing activity in the order of full length CCL26 while TTK25 had no significant effect (all at $10 \mu \mathrm{M}$ ) (Figure 5C). In addition, both CCL11 and CCL24 displayed neutralizing activity in the order of CCL26 and GSD35.

\section{CCR3-activation}

The eotaxins bind and activate CCR3, resulting in cellular activation, e.g. chemotaxis of eosinophils (11). Intracellular signaling of CCR3 includes increases in intracellular calcium concentrations. To investigate whether GSD35 or TTK25 affect CCR3-signaling, a transfected cell-line stably expressing CCR3 was loaded with the calcium-sensitive probe Fluo-4 and Fura red and followed by stimulation with CCL11, CCL24, and CCL26 (all at $100 \mathrm{nM}$ ) that all induced mobilization of calcium (Figure 6).

This article is protected by copyright. All rights reserved. 
In contrast, neither GSD35 nor TTK25 had any activity at the same concentrations (Figure 6). Nor did co-incubation with GSD 35 or TTK25 interfere with the CCR3-signaling induced by full CCL11, CCL24, or CCL26 (not shown). Furthermore, chemotaxis experiments with primary eosinophils, using full-length CCL26 and the fragments TTK25 and GSD35, showed that the fragments lacked chemotactic activity (Figure 6B).

\section{DISCUSSION}

In this study, we show that eotaxin-1/CCL11, eotaxin-2/CCL24, and eotaxin-3/CCL26 have potent bactericidal activity against several important bacterial airway pathogens. We also show that the effect, at least in part, is mediated through disruption of bacterial membranes. In the case of CCL26, the antibacterial activity is localized to the $\mathrm{COOH}$-terminal region of the molecule. The mast cell proteases chymase and tryptase cleave off distinct fragments where the $\mathrm{NH}_{2}$-terminal fragment GSD35 has potent LPS-neutralizing activity in the order of the full length CCL26 while the COOHterminal fragment TTK25 retain bactericidal activity.

Several chemokines possess defensin-like antibacterial activity, e.g. MIG/CXCL9, CCL20, and CCL28 (6-8). Some of these are constitutively expressed, e.g. CCL28 while transcription of MIG/CXCL9 is induced by the prototypic Th1 cytokine IFN- $\gamma(20)$. The expression of eotaxins are induced by IL- 4 during allergic inflammation, where CCL11 may be expressed during an earlier phase while CCL24 and CCL26 are expressed during the late allergic response which is characterized by an influx of eosinophils (21). To our knowledge, this is the first report demonstrating antibacterial activity of chemokines expressed during a Th2 skewed inflammatory response.

It is interesting that CCL26 retain its bactericidal in the presence of salt, while many other AMPs, for example $\beta$-defensins are salt-sensitive (3). The concentration of sodium chloride in the periciliary

This article is protected by copyright. All rights reserved. 
liquid has been a matter of debate but recently experimental data suggested it to be close to that of plasma, i.e. around $140 \mathrm{mM}$ (16). The eotaxins have very similar structures even though their primary sequences are quite different (Supporting Information Supplemental Figure 1). Since cationicity is an important feature, reflecting the antibacterial activity of many HDPs, this may explain the higher activity of CCL26 since it has the highest $\mathrm{pI}$ and net charge of the eotaxins (Supporting Information Table 1).

Can the eotaxins reach bactericidal levels in vivo? The depth of the PCL covering the airway epithelium is around $4 \mu \mathrm{m}$ (22). Thus, the liquid compartment wherein HDPs and eotaxins are dissolved is minute and micromolar concentrations exerting bactericidal activity are likely to be present as demonstrated for other antibacterial chemokines in vivo (i.e. midkine at $3 \mu \mathrm{M}$ and BRAK/CXCL14 at $9 \mu \mathrm{M})(23)$.

Recent studies have shown an association between asthma and susceptibility to respiratory pathogens. Among the bacterial microorganisms involved, S. pneumoniae is the most common pathogen and the risk of invasive pneumococcal disease (IPD) is increased in asthma (24-26). There are conflicting reports as whether allergic airway inflammation per se increases the vulnerability to acquire airway infection. In a mice model using $P$. aeruginosa, allergic inflammation impaired airway host defense against this bacterium while in a model using $S$. pneumoniae, no increased susceptibility was observed $(27,28)$. In individuals suffering from asthma, other factors are likely to contribute, for example treatment with inhaled corticosteroids that doubles the risk of pneumonia in asthma (29).

There is an obvious redundancy having three chemokines that exclusively activate CCR3. However, CCL26 has the highest CCR3-activating activity of the eotaxins, and CCL24 and CCL26 but not CCL11 increase with asthma severity $(21,30)$.

This article is protected by copyright. All rights reserved. 
In this study, we show that both CCL26 and the fragment GSD35 have LPS-neutralizing properties. To our knowledge, this is the first demonstration of this property in a chemokine. LPS has since long been recognized as an enhancer of allergic inflammation in asthma and CCL26 may also modulate the allergic inflammatory response in this aspect (31). In a previous study, it was demonstrated that tryptase abrogated the chemotactic properties of CCL11 (32). We found that chymase completely degraded CCL11 while no or minute proteolytic activity was observed for CCL24. In our hands, neither CCL11 nor CCL24 was affected by tryptase (Supplemental Figure 2). Further supporting biological relevance of our findings is an animal study where mice were challenged with house dust mite (HDM) extract to induce allergic airway inflammation. Animals deficient in mouse mast cell protease 4 (mMCP4; the murine counterpart to human chymase) had a more pronounced eosinophilia in bronchoalveolar fluid compared with wild type mice (33). In this study, it was shown that chymase degrades the Th2-promoting cytokine IL-33. However, effects on eotaxins are also possible.

Both chymase and tryptase are serine-proteases, chymase cleaving after aromatic amino acids, i.e. phenylalanine $(\mathrm{F})$, tyrosine $(\mathrm{Y})$, and tryptophane $(\mathrm{W})$, while tryptase cleaves after arginine $(\mathrm{R})$ and lysine $(\mathrm{K})$ residues. The TTK25 fragment generated by chymase is indeed generated through cleavage of CCL26 after arginines. The GSD35 fragment is generated by cleavage after a phenylalanine, consistent with the specificity of the enzyme, but after a lysine in its $\mathrm{COOH}-$ terminus. However, an absolute specificity for serine-proteases has been questioned and this can also be the case for chymase and tryptase of mast cells (34). The fragment generated by supernatants from degranulated mast cells was identical to GSD35, deduced from a combination of N-terminal sequencing and MS/MS but appeared slightly smaller on SDS-PAGE. It is likely to have biological properties similar to that of GSD35.

The current findings suggest that the eotaxins, in addition to recruiting and activating eosinophils, may play several roles in innate host defense of the airways during allergic inflammation.

This article is protected by copyright. All rights reserved. 


\section{Acknowledgements}

We wish to express our sincere gratitude to Pia Andersson and Maria Baumgarten for skillful technical assistance and Dr. Björn Walse, Saromics, Lund, for molecular models.

This work was supported by the Swedish Research Council, the Swedish Heart and Lung Foundation, the Swedish Foundation for Strategic Research, the Swedish Government Funds for Clinical Research (ALF), the foundations of Bergh, Greta \& Johan Kock, the Phyiographic Society, and Alfred Österlund.

\section{Conflict of interest statement}

All authors declare no conflict of interest related to the content of this work.

\section{Author contributions}

AG, GK, ME, GN, AS, and AE contributed to the conception and design of the study, and AE supervised the project. AG, SJ, ME, MM, and SK performed the experiments. AG, GK, SJ, MM, SK, AS, and AE conducted data analysis and interpretation of results. AG and AE wrote the manuscript.

\section{References}

1. Singh PK, Tack BF, McCray PB Jr, Welsh MJ. Synergistic and additive killing by antimicrobial factors found in human airway surface liquid. Am J Physiol Lung Cell Mol Physiol 2000;279:L799805.

This article is protected by copyright. All rights reserved. 
2. Bals R, Wang X, Zasloff M, Wilson JM. The peptide antibiotic LL-37/hCAP-18 is expressed in epithelia of the human lung where it has broad antimicrobial activity at the airway surface. Proc Natl Acad Sci U S A 1998;95:9541-9546.

3. Bals R, Wang X, Wu Z, Freeman T, Bafna V, Zasloff M, Wilson JM. Human beta-defensin 2 is a salt-sensitive peptide antibiotic expressed in human lung. J Clin Invest 1998;102:874-880.

4. Harder J, Bartels J, Christophers E, Schroder JM. Isolation and characterization of human $\beta$ defensin-3, a novel human inducible peptide antibiotic. J Biol Chem 2001;276:5707-5713.

5. Kolls JK, McCray PB Jr, Chan YR. Cytokine-mediated regulation of antimicrobial proteins. Nat Rev Immunol 2008;8:829-35.

6. Cole AM, Ganz T, Liese AM, Burdick MD, Liu L, Strieter RM. Cutting edge: IFN-inducible ELRCXC chemokines display defensin-like antimicrobial activity. J Immunol 2001;167:623-627.

7. Yang D, Chen Q, Hoover DM, Staley P, Tucker KD, Lubkowski J, Oppenheim JJ. Many chemokines including CCL20/MIP-3alpha display antimicrobial activity. J Leukoc Biol 2003;74:448455.

This article is protected by copyright. All rights reserved. 
8. Hieshima K, Ohtani H, Shibano M, Izawa D, Nakayama T, Kawasaki Y, Shiba F, Shiota M, Katou F, Saito T, Yoshie O. CCL28 has dual roles in mucosal immunity as a chemokine with broadspectrum antimicrobial activity. J Immunol 2003;170:1452-61.

9. Burkhardt AM, Tai KP, Flores-Guiterrez JP, Vilches-Cisneros N, Kamdar K, Barbosa-Quintana O, Valle-Rios R, Hevezi PA, Zuñiga J, Selman M, Ouellette AJ, Zlotnik A. CXCL17 is a mucosal chemokine elevated in idiopathic pulmonary fibrosis that exhibits broad antimicrobial activity. $J$ Immunol 2012;188:6399-6406.

10. Linge HM, Collin M, Nordenfelt P, Mörgelin M, Malmsten M, Egesten A. The human CXC chemokine granulocyte chemotactic protein 2 (GCP-2)/CXCL6 possesses membrane-disrupting properties and is antibacterial. Antimicrob Agents Chemother 2008;52:2599-2607.

11. Pease JE, Williams TJ. Chemokines and their receptors in allergic disease. J Allergy Clin Immunol 2006;118:305-318.

12. Crump MP, Rajarathnam K, Kim KS, Clark-Lewis I, Sykes BD. Solution structure of eotaxin, a chemokine that selectively recruits eosinophils in allergic inflammation. $J$ Biol Chem 1998;273:22471-22479.

13. Pejler G, Rönnberg E, Waern I, Wernersson S. Mast cell proteases: multifaceted regulators of inflammatory disease. Blood 2010;115:4981-4990.

This article is protected by copyright. All rights reserved. 
14. Jounio U, Juvonen R, Bloigu A, Silvennoinen-Kassinen S, Kaijalainen T, Kauma H, Peitso A, Saukkoriipi A, Vainio O, Harju T, Leinonen M. Pneumococcal carriage is more common in asthmatic than in non-asthmatic young men. Clin Respir J. 2010;4:222-229.

15. Zhang Q, Illing R, Hui CK, Downey K, Carr D, Stearn M, Alshafi K, Menzies-Gow A, Zhong N, Fan Chung K. Bacteria in sputum of stable severe asthma and increased airway wall thickness. Respir Res. 2012;13:35.

16. Pezzulo AA, Tang XX, Hoegger MJ, Alaiwa MH, Ramachandran S, Moninger TO, Karp PH, Wohlford-Lenane CL, Haagsman HP, van Eijk M, Bánfi B, Horswill AR, Stoltz DA, McCray PB Jr, Welsh MJ, Zabner J. Reduced airway surface $\mathrm{pH}$ impairs bacterial killing in the porcine cystic fibrosis lung. Nature 2012;487:109-113.

17. Boman HG. Antibacterial peptides: basic facts and emerging concepts. J Intern Med 2003;254:197-215.

18. Gant VA, Warnes G, Phillips I, Savidge GF. The application of flow cytometry to the study of bacterial responses to antibiotics. J Med Microbiol 1993;39:147-54.

19. Larrick JW, Hirata M, Balint RF, Lee J, Zhong J, Wright SC. Human CAP18: a novel antimicrobial lipopolysaccharide-binding protein. Infect Immun 1995;63:1291-1297.

This article is protected by copyright. All rights reserved. 
20. Liao F, Rabin RL, Yannelli JR, Koniaris LG, Vanguri P, Farber JM. Human Mig chemokine: biochemical and functional characterization. J Exp Med 1995;182:1301-14.

21. Coleman JM, Naik C, Holguin F, Ray A, Ray P, Trudeau JB, Wenzel SE. Epithelial eotaxin-2 and eotaxin-3 expression: relation to asthma severity, luminal eosinophilia and age at onset. Thorax 2012;67:1061-1066.

22. Chen JH, Stoltz DA, Karp PH, Ernst SE, Pezzulo AA, Moninger TO, Rector MV, Reznikov LR, Launspach JL, Chaloner K, Zabner J, Welsh MJ. Loss of anion transport without increased sodium absorption characterizes newborn porcine cystic fibrosis airway epithelia. Cell 2010;143:911-923.

23. Frick IM, Nordin SL, Baumgarten M, Mörgelin M, Sørensen OE, Olin AI, Egesten A. Constitutive and inflammation-dependent antimicrobial peptides produced by epithelium are differentially processed and inactivated by the commensal Finegoldia magna and the pathogen Streptococcus pyogenes. J Immunol 2011;187:4300-4309.

24. Talbot TR, Hartert TV, Mitchel E, Halasa NB, Arbogast PG, Poehling KA, Schaffner W, Craig AS, Griffin MR. Asthma as a risk factor for invasive pneumococcal disease. $N$ Engl J Med 2005;352:2082-2090.

25. Juhn YJ, Kita H, Yawn BP, Boyce TG, Yoo KH, McGree ME, Weaver AL, Wollan P, Jacobson RM. Increased risk of serious pneumococcal disease in patients with asthma. J Allergy Clin Immunol 2008;122:719-723.

This article is protected by copyright. All rights reserved. 
26. Klemets P, Lyytikäinen O, Ruutu P, Ollgren J, Kaijalainen T, Leinonen M, Nuorti JP. Risk of invasive pneumococcal infections among working age adults with asthma. Thorax 2010;65:698-702.

27. Beisswenger C, Kandler K, Hess C, Garn H, Felgentreff K, Wegmann M, Renz H, Vogelmeier C, Bals R. Allergic airway inflammation inhibits pulmonary antibacterial host defense. J Immunol 2006;177:1833-1837.

28. Clement CG, Tuvim MJ, Evans CM, Tuvin DM, Dickey BF, Evans SE. Allergic lung inflammation alters neither susceptibility to Streptococcus pneumoniae infection nor inducibility of innate resistance in mice. Respir Res 2009;10:70.

29. McKeever T, Harrison TW, Hubbard R, Shaw D. Inhaled corticosteroids and the risk of pneumonia in people with asthma: a case-control study. Chest 2013;144:1788-94.

30. Provost V, Larose MC, Langlois A, Rola-Pleszczynski M, Flamand N, Laviolette M. CCL26/eotaxin-3 is more effective to induce the migration of eosinophils of asthmatics than CCL11/eotaxin-1 and CCL24/eotaxin-2. J Leukoc Biol 2013;94:213-22.

31. Michel O, Kips J, Duchateau J, Vertongen F, Robert L, Collet H, Pauwels R, Sergysels R. Severity of asthma is related to endotoxin in house dust. Am J Respir Crit Care Med 1996;154:16411646.

This article is protected by copyright. All rights reserved. 
32. Pang L, Nie M, Corbett L, Sutcliffe A, Knox AJ. Mast cell beta-tryptase selectively cleaves eotaxin and RANTES and abrogates their eosinophil chemotactic activities. $J$ Immunol 2006;176:3788-3795.

33. Waern I, Lundequist A, Pejler G, Wernersson S. Mast cell chymase modulates IL-33 levels and controls allergic sensitization in dust-mite induced airway inflammation. Mucosal Immunol 2013;6:911-920.

34. Rodriguez J, Gupta N, Smith RD, Pevzner PA. Does trypsin cut before proline? J Proteome Res. 2008;7:300-305.

\section{Figure Legends}

Figure 1. Bactericidal activity of eotaxins.

(A) The bactericidal activity of eotaxin-1/CCL11, eotaxin-2/CCL24, eotaxin-3/CCL26, and the classical antibacterial peptide LL-37 against Streptococcus pneumoniae and Non-typeable Haemophilus influnzae ( $\mathrm{NtHi}$ ) was investigated by means of a viable count assay. Briefly, bacteria were grown to mid-logarithmic phase and incubated for 60 min with CCL11, CCL24, CCL26, and LL-37 respectively at the indicated concentrations or in buffer alone. Antibacterial activity was quantified by making serial dilutions of the cultures followed by plating on agar plates. Following overnight incubation, the \% killing of peptides was determined by comparing the number of colony forming units remaining on the plate after peptide exposure versus the cultures incubated in buffer alone.

(B) Furthermore, the ability of CCL11, CCL24, and CCL26 respectively to kill bacteria was investigated in the presence of sodium chloride $(140 \mathrm{mM})$ using the same procedure as described

This article is protected by copyright. All rights reserved. 
above. The data shown represent the mean, $\pm \mathrm{SD}$ from three separate experiments. Statistical significance was determined using two-way ANOVA, $* * P<0.01$.

\section{Figure 2. Morphological changes of bacteria caused by the eotaxins.}

Gram-positive (i.e. S. pneumoniae or S. aureus) and Gram-negative (i.e. NtHi or P. aeruginosa) were incubated in buffer alone or with CCL11, CCL24, CCL26, and LL-37 respectively at $1 \mu \mathrm{M}$ for one hour at $37^{\circ} \mathrm{C}$. Parts of the samples were processed for scanning electron microscopy (SEM) and the other part was used in viable count assay to confirm bacterial killing. Intact bacteria are seen after incubation in buffer alone while incubation with CCL11, CCL24, CCL26, and LL-37 all cause blebbing, protrusions, and leakage of intracellular contents. Bar=100 nm.

Figure 3. Permeabilizing effect of eotaxin as measured by uptake of vital dyes. (A) S. pneumoniae was incubated in buffer alone, with CCL26 or with LL37 $(1 \mu \mathrm{M})$ for one hour at $37^{\circ} \mathrm{C}$. The ability of CCL26 to permeabilize the membrane was assessed using FITC, a cell impermeant probe, followed by fluorescence microscopy. After incubation in buffer alone, scarce bacteria have lost their integrity allowing entrance of FITC while after incubation with CCL26 and LL37 respectively, a large number of bacteria have lost their integrity and become fluorescent.

(B), The bacterial internalization of propidium iodide (PI) was investigated. S. pneumoniae was incubated in buffer alone or with CCL26 $(1 \mu \mathrm{M})$. Parts of the bacterial solution were used for viable counts to confirm killing and parts were used for flow cytometry. In permeabilized bacteria, PI was internalized and bound to DNA, resulting in red fluorescence. The data shown represent mean and SD of three separate experiments. Statistical significance was determined using two-way ANOVA, ** $P<0.01$.

This article is protected by copyright. All rights reserved. 


\section{Figure 4. Mapping of regions with antibacterial activity in CCL26.}

(A) Synthetic 20-mer peptides, stepwise covering full-length CCL26 were synthesized (the sequences are shown on the left) and used in a radial diffusion assay (RDA) with P. aeruginosa and S. aureus, respectively. Clear zones around the wells were measured, reflecting the antimicrobial activity of the amino acid fragment. The highest antibacterial activity was seen in the $\mathrm{COOH}$-terminal region of CCL26 where also a high positive net charge and $\mu$ Hrel (relative hydrophobicity) are found. The data shown represent mean and SD from three separate experiments. The sequence of full length CCL26 is shown (bottom) and the distribution of charged amino acids and antibacterial activity are indicated.

\section{Figure 5. Processing of CCL26 by mast cells proteases.}

(A) To investigate if the serine-proteases, released by mast cells during allergic inflammation, will cleave CCL26, incubation with the respective enzyme (chymase and tryptase) was performed for 18 hours at $37^{\circ} \mathrm{C}$, followed by separation using SDS-PAGE. Both chymase and tryptase generated distinct fragments from CCL26. The fragments were analyzed by mass spectrometry and $\mathrm{NH}_{2}$ terminal sequencing and a 35 amino acid fragment was derived from the $\mathrm{NH}_{2}$-terminal region (GSD35; orange in the model of the full length protein) by tryptase and a 25 amino acid fragment from the $\mathrm{COOH}$-terminus (TTK25; green in the model of the full length protein) was generated by chymase. Proteolytic digest with supernatant of degranulated mast cells released a fragment identical to GSD35 (N-terminal sequencing combined with MS/MS) but appearing slightly smaller on SDSPAGE (arrowhead). Preincubation of mast cell supernatant with Pefabloc SC (broad spectrum serine protease inhibitor) resulted in disappearance of the fragment. Putative cleavage sites for chymase (red) and tryptase (blue) are indicated in the full-length sequence of CCL26.

(B) The bactericidal activity of TTK25 and GSD35 was compared with the full length CCL26 using a viable count assay. TTK25 and GSD35 were incubated with $S$. pneumoniae or NtHi for one hour followed by viable counts. In both cases, TTK25 displayed a dose dependent bactericidal activity in

This article is protected by copyright. All rights reserved. 
the order of full length CCL26 compared with GSD35. The results shown represent mean and SD of three separate experiments.

(C) The LPS-neutralizing activity of the full length CCL26 and the fragments respectively, was investigated using a monocytic cell-line (THP-1) transfected with a NF-kappaB responsive element where activation results in production of alkaline phosphatase (ALP). LPS of $P$. aeruginosa (final concentration $100 \mathrm{ng} / \mathrm{ml}$ ) was preincubated for 20 minutes in medium alone or with full length CCL26, GSD35, and TTK25 (all at a final concentration of $10 \mu \mathrm{M}$ ) followed by incubation with the cell-line for 24 hours. The ALP-activity was used as readout and the response to LPS alone at 100 $\mathrm{ng} / \mathrm{ml}$ was set to $100 \%$. Both full length CCL26 and GSD35 significantly reduced NF-kappaB activation, GSD35 having potency in the order of CCL26. TTK25 displayed a non-significant reduction of NF-kappaB activation. CCL11 and CCL24 both displayed LPS-neutralizing activity in the order of CCL26 and GSD35. The data represent mean and SD from three separate experiments. Statistical significance was determined using two-way ANOVA, $* * P<0.01$.

\section{Figure 6: Receptor-interacting properties of TTK-25 and GSD-35.}

(A) A murine cell line stably expressing human CCR3 were loaded with the calcium-sensitive probe Fluo-4 and Fura-red, thereafter stimulated with CCL11, CCL24, and CCL26 respectively (all at 100 $\mathrm{nM}$ ). Each chemokine elicited a similar mobilization of intracellular calcium. One representative out of three experiments is shown.

The CCL26-derived fragments TTK25 and GSD35 (each at $100 \mathrm{nM}$ ) did not induce detectable mobilization of intracellular calcium. One representative out of three experiments is shown. Nor did the fragments interfere with the receptor-activating properties of CCL11, CCL24, or CCL26 when coincubated (not shown).

(B) Eosinophils, purified by negative magnetic selection, were allowed to migrate in response to increasing concentrations of CCL26, GSD35, or TTK25. The chemotactic response is expressed as a

This article is protected by copyright. All rights reserved. 
ratio of the migration observed in response to buffer alone (chemotactic index). The data represent mean and SD from three separate experiments.

Table 1: Anele et al

Table 1: Biophysical properties of CCL26-derived peptides

\begin{tabular}{lllll} 
& No of amino acids & Net charge & $\begin{array}{l}\text { Isoelectric } \\
\text { point }\end{array}$ & Molecular weight (KDa) \\
\hline CCL26 & 71 & +13 & 10.2 & 8.3 \\
TTK25 & 25 & +9 & 10.8 & 3.0 \\
GSD35 & 35 & +2 & 8.6 & 4.1 \\
\hline
\end{tabular}

This article is protected by copyright. All rights reserved. 
Figure 1: Anele et al
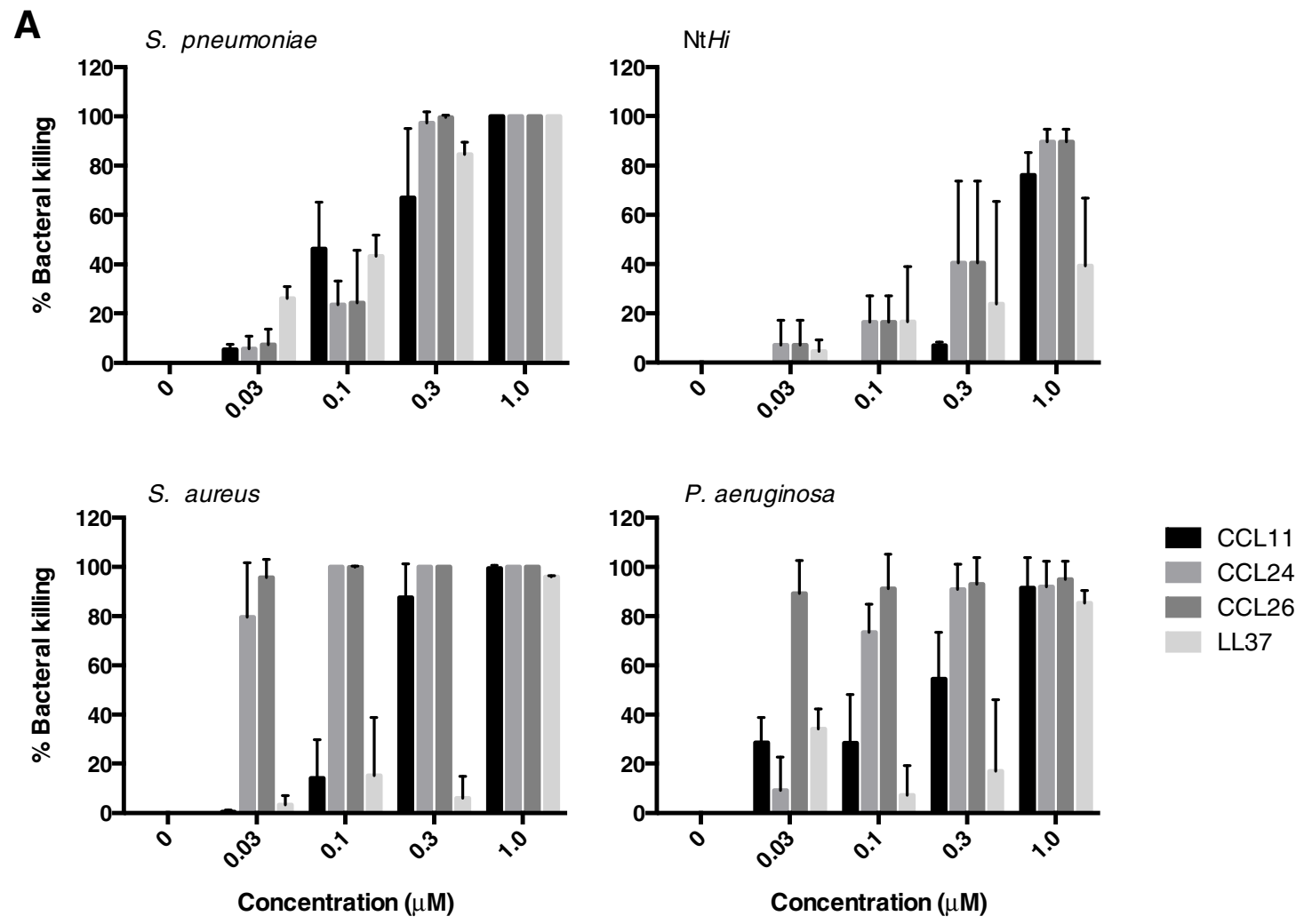

B

S. pneumoniae

$N+H i$
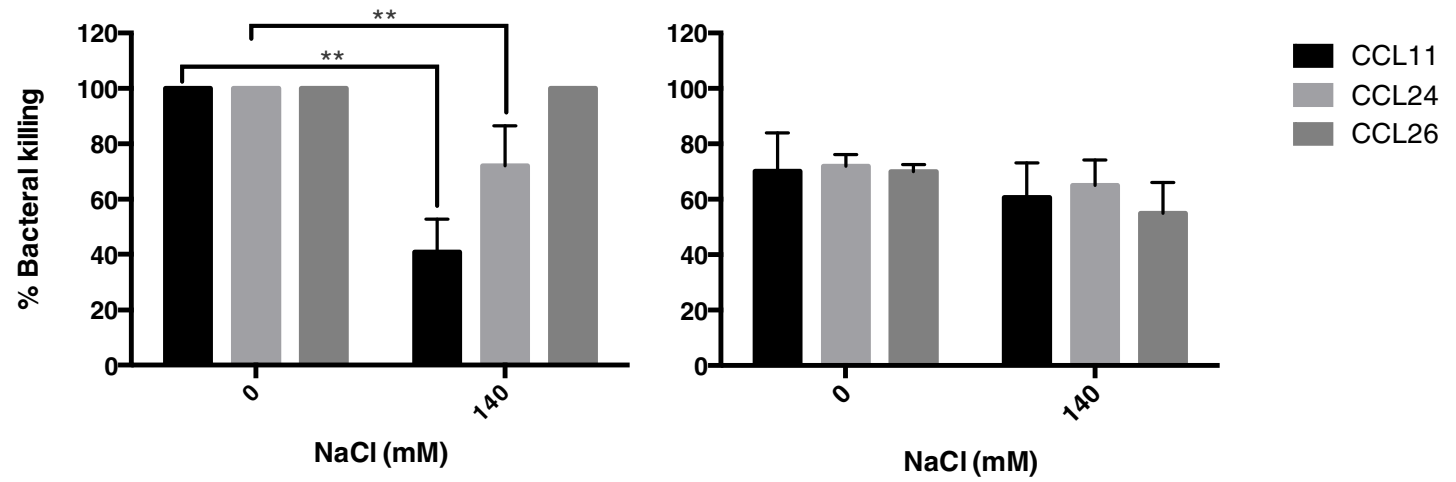

This article is protected by copyright. All rights reserved. 
Figure 2: Anele et al

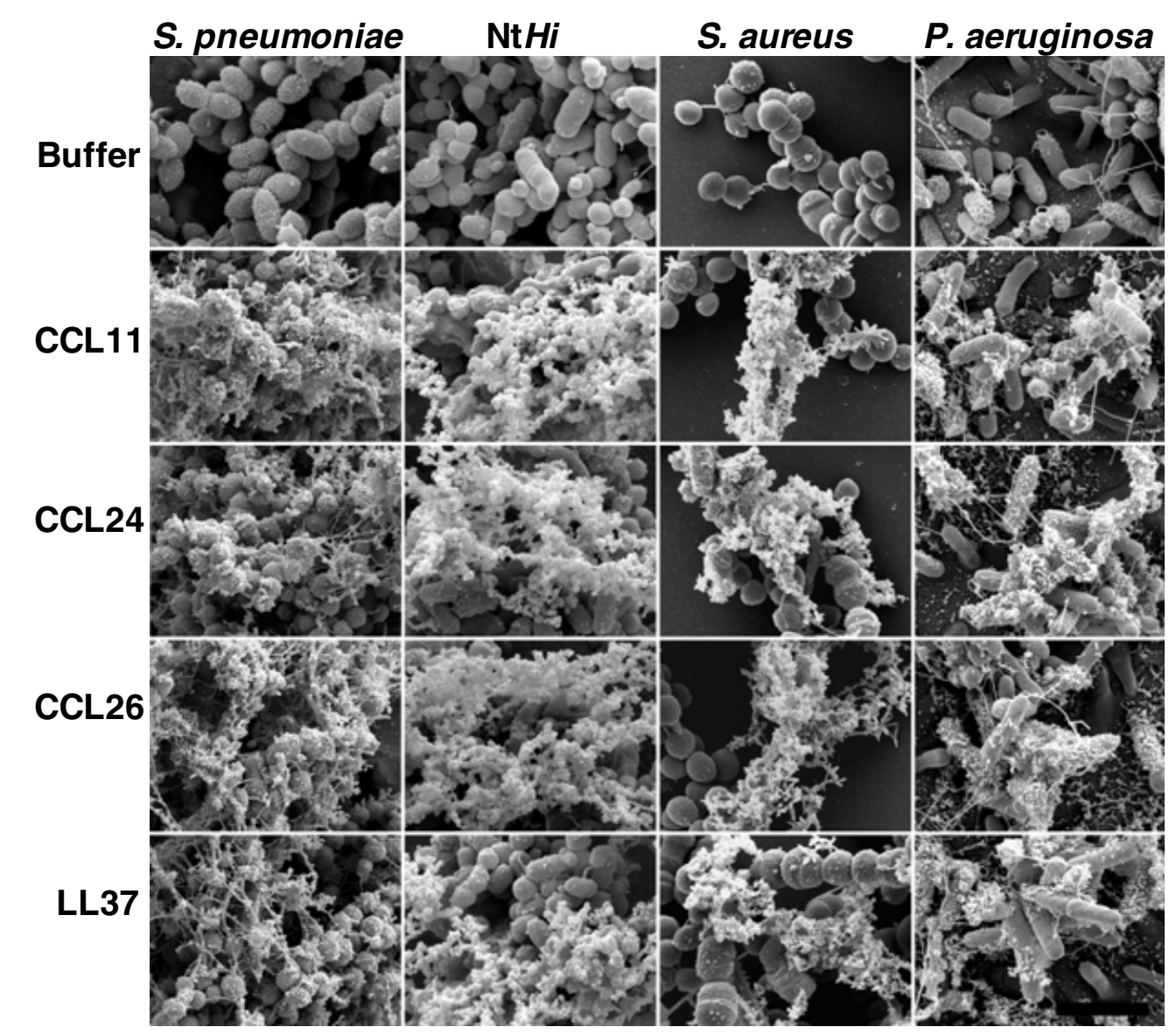

This article is protected by copyright. All rights reserved. 
Figure 3: Anele et al
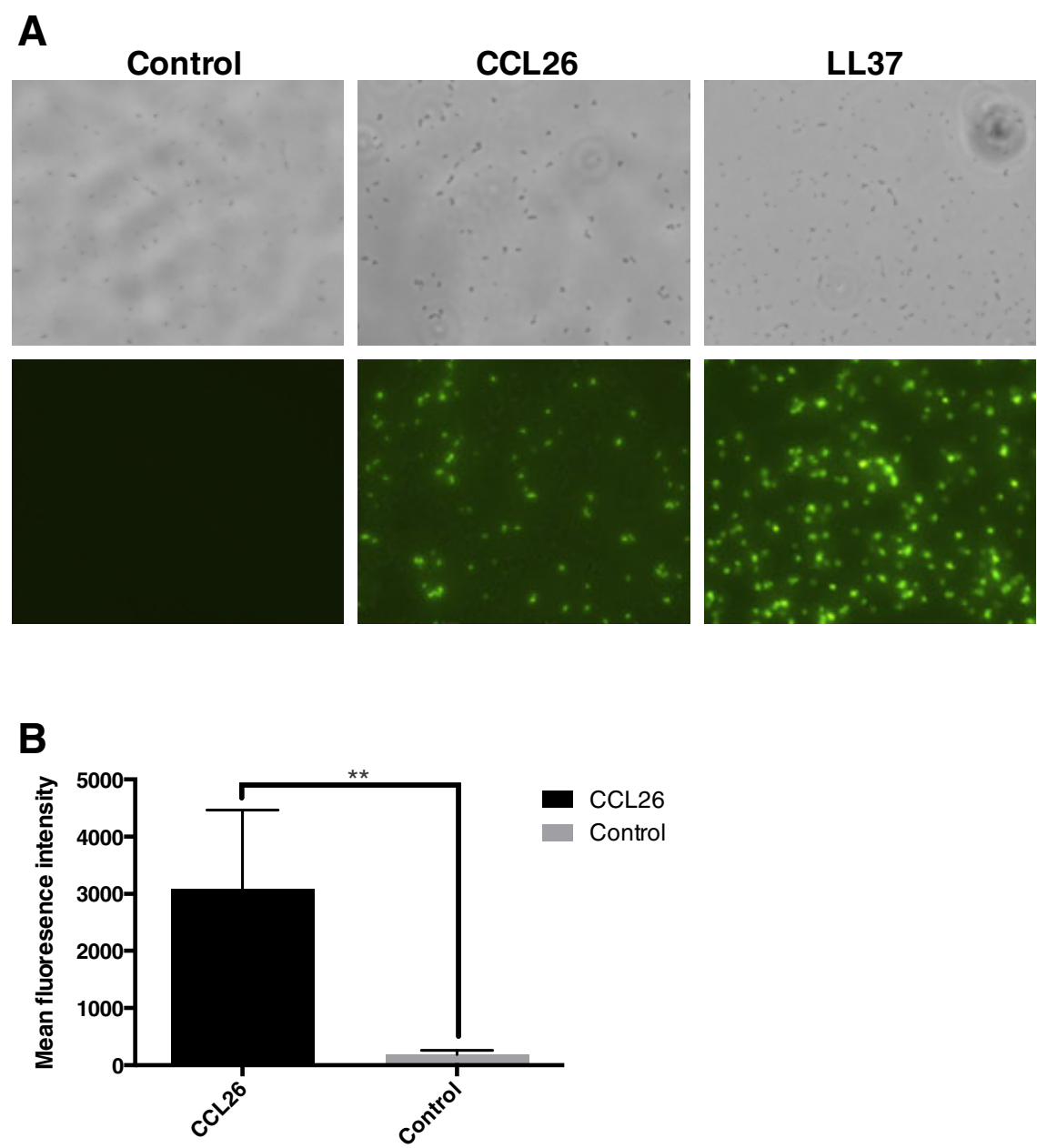

This article is protected by copyright. All rights reserved. 
Figure 4: Anele et al

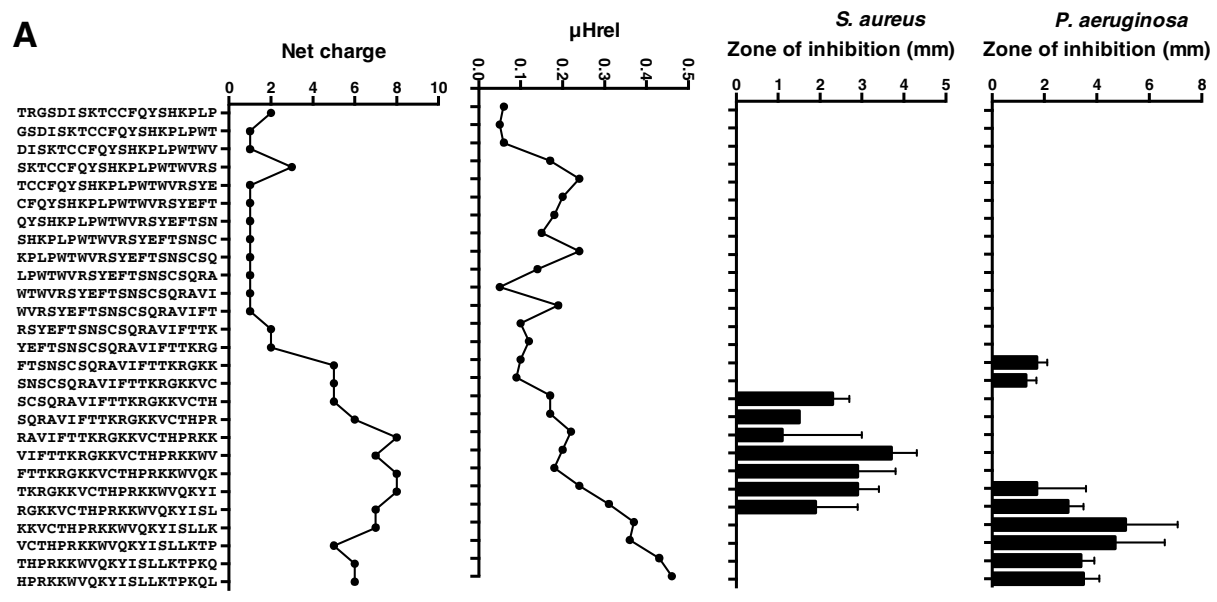

B

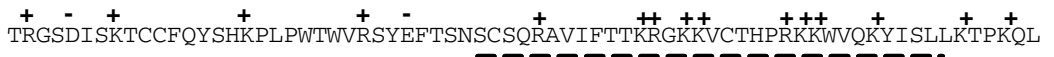
-ー-ー-ーー-ーー-ー-ー- -

- - Antibacterial activity against $S$. aureus

- Antibacterial activity against $P$. aeruginosa

This article is protected by copyright. All rights reserved. 

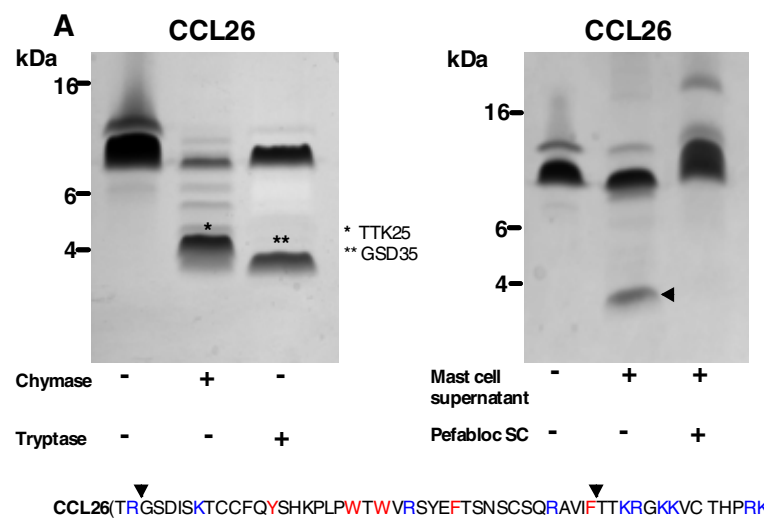

Figure 5: Anele et al

CCL26(TRGSDISKTCCFQYSHKPLPWTWVRSYEFTSNSCSQRAVIFTTKRGKKVC THPRKKWVQKYISLKTPKQL)

B

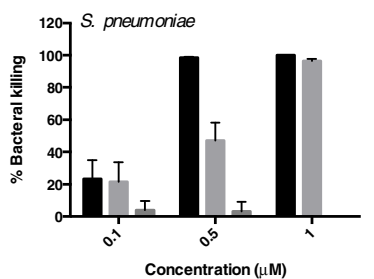

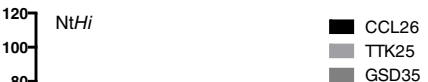

C

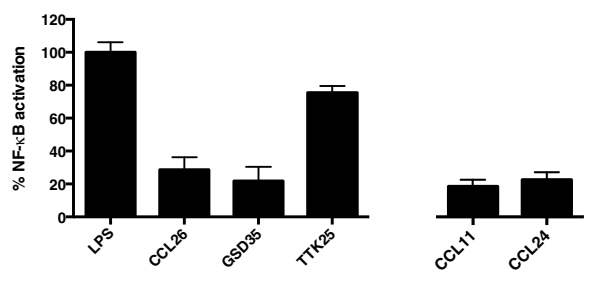

This article is protected by copyright. All rights reserved. 
A

Figure 6: Anele et al
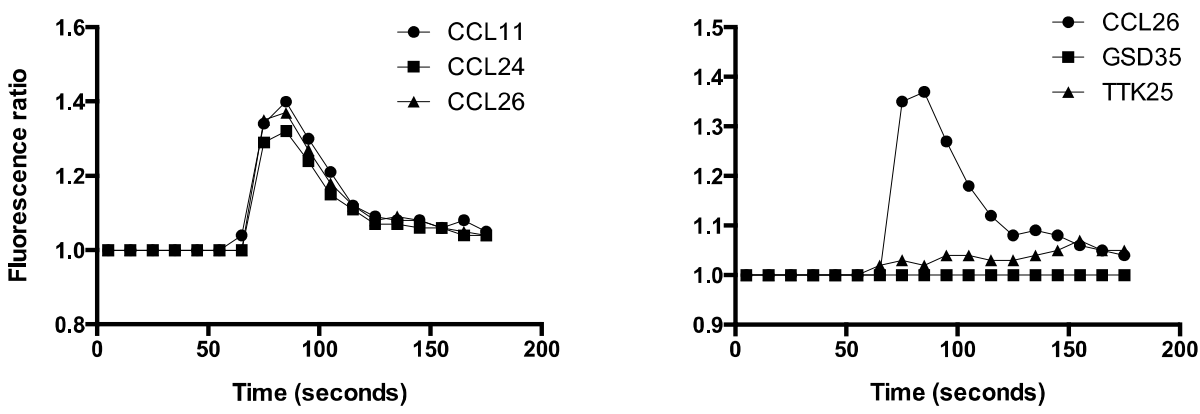

B

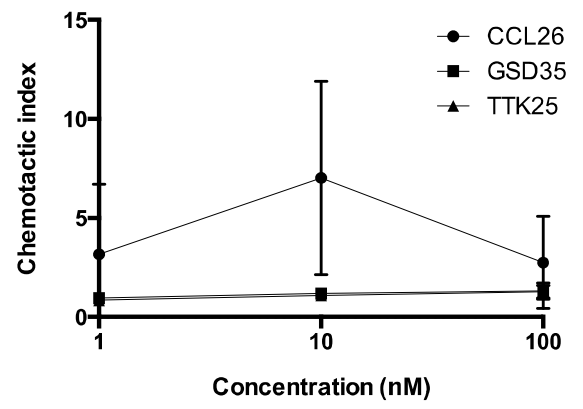

This article is protected by copyright. All rights reserved. 